\title{
Humanism in the punishment of Russian criminal law
}

\author{
Stanislav Rozenko* \\ Yugra State University, Yugra, Khanty-Mansiysk, Russia
}

\begin{abstract}
The article is devoted to the analysis of the problems of development and improvement of humanism in Russian criminal law. The principle of humanism is analyzed as a complex-systemic legal phenomenon with its own content and logic of development. Since punishment is a social phenomenon and functions in various areas of state and public life, its development is due to the implementation of a humanistic approach in law. The article examines the significance of humanism in criminal punishment and its historical nature; the essence of criminal punishment is defined in the Criminal Code of the Russian Federation as a list of types of punishments that are directly represented as a system and are applied to the guilty in the form of a measure of punishment, but humanism systematically limits the boundaries of criminal repression. Based on this analysis, the author makes judgments that at present humanism in the punishment of Russian law should be considered as a prerequisite for the formalization of punishment and other measures of a criminal law nature as independent and equal institutions of Russian criminal law. The consolidation of the constitutional prohibition on cruel or degrading punishment (part 2 of article 21 of the Constitution of the Russian Federation) necessitates a conceptual definition of these terms in the Criminal Code of the Russian Federation.
\end{abstract}

\section{Introduction}

The urgency of the problem of consolidating humanism in Russian criminal law is due to the complex and lengthy processes of interaction between punishment and humanism. This problem is due to the current trends in the development of the criminal legislation of Russia and the challenges of the modern socio-economic development of society and the state, where the principle of humanism has constitutional and legal significance, but its detailing in the Criminal Code of the Russian Federation is required.

In the Russian Federation, human and civil rights and freedoms are enshrined as a significant and inalienable value in the state and society. The principle of humanism was for the first time directly defined in the Criminal Code of the Russian Federation, but it should be noted that it also contains other provisions that have a humanistic orientation.

In Soviet and Russian criminal law, for several decades, a significant number of authors have studied various aspects of punishment: V.A. Avdeev, A.A. Aryamov, M.M. Babaev, E.V. Blagov, Yu.V. Golik, A.A. Gravina, V.K. Duyunov, D.S. Dyadkin, V.P. Kashepov, I. Ya. Kozachenko, N.A. Lopashenko, V.F. Lapshin, S.F. Milyukov, A.F. Mitskevich, T.V. Nepomnyashchaya, G.P. Novoselov, I.S. Noy, I.A. Podroykina, Yu.E. Pudovochkin, A.I. Rarog, A.V. Sumachev, A.V. Shesler, N.V. Shchedrin, P.S. Yani et al.

The concept of humanism has found wide application in scientific research: in philosophy, theory of law, cultural studies, history, political science; it is ambiguous and complex.

Humanism is humanity in social activities, in relation to people [1, p. 149].

In philosophy, humanism is formulated as a set of views, respect for human dignity and rights, its value as a person, care for the welfare of people, their all-round development, on the creation of favorable conditions for a person in public life [2, p. 103].

At the moment, there are many humanistic trends and theories. "Among the requirements that a modern mechanism makes to a person, we can name the following: personal, moral, civil or legal, aesthetic, intellectual, environmental. From the standpoint of humanism, there exists or should exist the equality of a person in relation to another person and society" $[3, p$. 42].

The interaction between the state and an individual should always be carried out in a legal form, since the protection of human rights and fundamental freedoms is always relevant. The recognition of the priority of the humanistic concept in law predetermined the construction of state and social institutions considering moral values.

In general, humanism can be viewed as an intersectoral principle of law, since in law a person is recognized as an integral social and state value.

A particular problem is the implementation of the provisions of humanism in criminal law. This is explained by the fact that for a long time, criminal coercion was based primarily on violence, punishment, repression. The ideas of $\mathrm{C}$. Beccaria in the middle of the

\footnotetext{
Corresponding author: rozenko_sv@mail.ru
} 
18th century served as the basis for new educational humanistic approaches to criminal punishment. During the 19th-20th centuries. in Russian (Soviet) criminal law, there was a combination of punitive and/or humanistic approaches in the formation of a system of types of punishment. When the 1996 Criminal Code of the Russian Federation was created, humanistic principles were given priority. This is confirmed by the fact that criminal punishment is based on the provisions of the Constitution of the Russian Federation of 1993: in Russian criminal law, only those human and civil rights and freedoms that fall under the scope of criminal law are mentioned.

\section{Results and Discussion}

Humanistic concepts of human rights have been discussed and substantiated for several centuries. In the period of New and Modern times, they received different design and at the present time, it is impossible to imagine more than one legal theory without the concept of the legal status of an individual.

The humanism of Russian criminal law is based on the provisions of international humanitarian law. In particular, according to the provisions of Art. 4 of the International Covenant on Economic, Social and Cultural Rights, restrictions on human rights by the state, in addition to being determined by law, must be compatible with the nature of these rights and be established solely for the purpose of promoting the general welfare in a democratic society. Moreover, restrictions on human rights cannot be discriminated solely on the basis of race, color, sex, language, religion or social origin.

International legal acts do not define the list of human and civil rights and freedoms that can be limited when applying criminal law.

The situation is solved in a similar way in the Constitution of the Russian Federation. But international acts and the Constitution of the Russian Federation contain separate restrictions on human rights and freedoms during the period of "a state of emergency in a state in which the life of the nation is under threat".

According to Part 3 of Art. 56 of the Constitution of the Russian Federation, in conditions of a state of emergency, the right to life; protection of the dignity of the individual and protection from torture, violence, cruel or degrading treatment; privacy; freedom of conscience and religion; free use of their abilities and property to engage in economic activities; dwelling; judicial protection of rights and freedoms cannot be limited.

The imposition of criminal punishment is not an emergency situation, but one should take into accountwith certain reservations - the clarifications of the Constitutional Court of the Russian Federation which in one of its decisions indicated that "there is a certain essence of a person that cannot be infringed upon and which cannot be sacrificed, and in all cases when doubts about the advisability of establishing restrictions on rights and freedoms occur, preference should be given to rights and freedoms, since the individual is not an object of state activity, but a full-fledged subject, which obliges the state to ensure respect for the dignity of the individual" [4]. The difficulty lies in establishing this essence. It seems beyond doubt that criminal punishment cannot be directed at the deprivation of the life of a person who has committed a crime.

In Art. 44 of the Criminal Code of the Russian Federation, the death penalty is provided for as a type of criminal punishment, but is currently not executed, which is due to the international obligations of the Russian Federation, as well as the decision of the Constitutional Court of the Russian Federation, which is determined in the decree of February 2, 1999 No. 3-P and the Definition of November 19, 2009 № 1344-O-P, according to which, from April 16, 1997, the death penalty should neither be imposed nor executed. A lengthy discussion about the death penalty in Russian legal science and this decision indicate that in Russian criminal law, the development of humanistic ideas is carried out in a complex way. In a number of cases, the criminal-legal content of humanism has distinctive features and differs from the general legal approach.

In the theory of criminal law, various approaches are expressed in defining humanism. V.P. Kashepov believes that the principle of humanism finds its manifestation in all sections of the RF Criminal Code [3, p. 47].

In our opinion, in the institution of punishment, humanism is not limited to the tasks of criminal law policy and other principles of criminal law, which are of equal importance.

There is no doubt that the development and improvement of the provisions of the principle of humanism in Russian criminal legislation, and, in particular, in the institution of punishment, is based on the basic principles of international law. The establishment of this principle in Russian criminal law is historically and socially conditioned. The limits of the punitive power of the state cannot be unlimited. Humanism is a consequence of the strengthening and development of the principles of criminal law in general. The principles of legality, equality of citizens before the law, guilt, justice and humanism are interconnected and interdependent.

The need for a scientific study of the problem of implementing the principle of humanism in criminal punishment is conditioned despite the legislative establishment of a system of principles of criminal law. The institution of criminal punishment is a priority and mandatory, since the main consequence of any crime is a specific form of state coercion-criminal punishment.

At present, the limits of criminal law impact in relation to persons who have committed a crime are significantly limited. In Art. 7 of the Criminal Code of the Russian Federation stipulates that the criminal legislation of the Russian Federation ensures human safety. Punishment and other measures of a criminal-legal nature applied to a person who committed a crime cannot be aimed at causing physical suffering or humiliation of human dignity. 
N.A. Lopashenko notes that the legislator makes no exceptions from the concept of "person" contained in Part 1 of Art. 7 of the Criminal Code. The provisions of this norm apply to both law-abiding citizens, including those illegally brought to justice, and to persons who have violated the criminal law. Of course, the rights and legally protected interests of these two categories of persons will be different [5, p. 256]. In our opinion, the principle of humanism cannot be selective, it extends its action to all subjects, but the limits of action may be different.

Humanism in criminal law developed consistently, along with punishment, which grew out of blood revenge, compensation, punishment and suffering. This process has been observed most significantly since the Enlightenment of the 18th century, when new approaches were presented for the heads of monarchies and the general public in the fight against crime. But, on the other hand, punishment as retribution from the state and society was limited to the provisions of justice and humanism for utilitarian purposes. The possibility of mitigating punishment is a manifestation of the prerogative of the expediency of state interests.

The consolidation of the principle of humanism in the Criminal Code of the Russian Federation is a natural result that has been achieved over a long period of time of constitutional legislative activity. Part 2 of Art. 21 of the Constitution of the Russian Federation determines the following: "No one should be subjected to torture, violence, other cruel or degrading treatment or punishment. No one can be subjected to medical, scientific or other experiments without voluntary consent". This consolidation is evidence of the implementation of the humanistic approach in the development of social life.

In the theory of Russian criminal law, various theories of punishment have been proposed and analyzed for a long time, but there is no doubt that the history of criminal law testifies to a tendency to mitigate punishment since the beginning of the 19th century: refusal from corporal and other similar types of punishment, restriction of the death penalty, etc.; attempts to find a supportive legal structure and/or an alternative to punishment. At the end of the 20th century. this process became predominant: the refusal of punishment and the priority of types of punishments not related to isolation from society, the consolidation of other measures of a criminal-legal nature as an independent criminal-legal institution. The construction of an industrial, post-industrial and informational societies required a significant adjustment of the content of individual measures of punishment, in general. If we pay attention to the presentation of the normative material in the criminal legislation, then it has become more dynamic; inter-sectoral interaction has been established; punishment has become an inter-sectoral legal category in Russian law. Currently, the construction of a digital society also forms a new publicstate order for the content and goals of criminal punishment, where the goal of restorative justice is a priority, not punishment.

Art. 18 of the Constitution of the Russian Federation established that the rights and freedoms of man and citizen are directly applicable. They determine the meaning, content and application of laws, the activities of the legislative and executive authorities, local selfgovernment and are provided by the coercive influence of justice.

In the Criminal Code of the Russian Federation, the principle of humanism is conditioned and limited by the action of other principles of criminal law: legality, equality of citizens before the law, guilt, justice, which allows concluding that the consolidation of the principles of criminal law had an impact on the separation of punishment and other measures of a criminal legal nature. If during the formation of criminal law the only reaction to a committed crime was punishment, then, at present, the Criminal Code of the Russian Federation provides for an extensive list of types of punishments and other criminal legal consequences.

Increasing criminal repression is a convenient means of combating crime, but the entire period of the application of criminal penalties testifies to the shortterm effect of harsh penalties.

The principle of humanism is not limited to the content of Art. 7 of the Criminal Code of the Russian Federation. Humanism as a universal requirement affects the limits of criminal law impact, the definition of the type and limits of the measure of criminal punishment, as well as the mitigation of criminal repression. It was the realization of humanism that determined the refusal of retribution in punishment. Humanism is declarative and comprehensive, as it is embodied in specific articles of criminal law.

A.I. Boyko writes, "The humanism of criminal law is dialectically contradictory: it is necessary to protect social foundations from the excesses of specific people and at the same time treat the invaders as real members of the affected society; showing compassion for the offender, remember the victim's offense" [6, pp. 55-56]. In our opinion, the improvement of humanism in criminal law is due to the criterion of goal-setting. Humanism is not something abstract, it must be verified, defined and formalized.

The development of the ideas of humanism in Russian criminal punishment served as the basis for the formation of the principles of restorative justice, which finds direct confirmation in the system of other measures of the criminal-legal nature of the Criminal Code of the Russian Federation.

In particular, the European Court of Human Rights considered the issue of the difference between punishment and measures related to the execution or application of punishment in the context of understanding the scope of Art. 7 of the 1950 European Convention for the Protection of Human Rights and Fundamental Freedoms and made a number of conclusions: punishment is applied exclusively on the basis of law, i.e. the principle that only law can determine the corpus delicti and provide for punishment in a number of its decisions; when certain legal restrictions are related to release from punishment (including early ones), when a law or other act introduces different approaches to the application of 
amnesty to various persons, then they do not belong to the institution of punishment from the point of view of substantive criminal law.

The Court has pointed out that the distinction between a measure that constitutes a "punishment" and a measure that refers to the "application" of a penalty is not always formalized precisely. For example, it acknowledged that the term "court-imposed punishment" could not be interpreted as excluding all measures from the scope of the Convention that were applied after the sentencing was announced. Consequently, where measures taken by the legislature, the executive or the courts after a final sentence or while serving a sentence result in a review or change of the content of a "sentence" imposed by a court, such measures should fall within the scope of a retrospective prohibition punishing the basis of the law. In order to determine whether the measure taken during the execution of the sentence affects only the way of execution of the sentence or, on the contrary, the scope of its application, in each case the court must examine what the imposed "punishment" actually entailed in accordance with the current national legislation, in other words, what constituted its actual meaning [7].

For example, it admitted that the concept of "Deprivations and restrictions provided for in criminal punishment" are detailed in federal legislation. But they have a complex structure, as they are provided for in various regulatory legal acts.

In the decisions of the Constitutional Court of the Russian Federation, the problem of the content of legal restrictions was considered, which, on the one hand, are not the essence and content of criminal punishment, but are mutually dependent due to it as elements of the punishment regime or the conditions for serving and applying it, as provided for in the criminal executive legislation.

The court adheres to the principled position according to which, when establishing criminal penalties with a different set of restrictions corresponding to the severity of the crime committed by the convicted person and the punishment imposed on him, as well as determining the procedure for serving this punishment, the legislator must proceed from the fact that convicts have, in general, the same rights and freedoms as other citizens, with exemptions due to the peculiarities of their personality and the crimes they have committed. The conditions for serving a sentence are aimed at individualizing punishment, differentiating penalties and their application, and create the prerequisites for achieving the goals of punishment [8].

In this case, the Constitutional Court of the Russian Federation establishes two mandatory conditions for legal restrictions due to the imposition of punishment: the nature and degree of public danger of the crime committed and the personality of the person who committed the crime.

By regulating the conditions for serving a sentence, the legislator is obliged to introduce only the necessary restrictions, ensuring, if possible, not only the lawabiding behavior of convicts during the period of serving the sentence and their correction, but also preparation for release, therefore the restrictions imposed, as well as the criteria for their differentiation must meet the requirements of justice, equality, proportionality, legality and humanism [9].

\section{Conclusion}

In our opinion, the following provisions testify to the implementation of the principle of humanism in the institution of criminal punishment:

1. Formalization of punishment and other measures of a criminal law nature as independent and equal institutions of Russian criminal law.

2. The principle of humanism interacts with the principle of justice, since the punishment must necessarily be just, according to Part 1 of Art. 60 of the Criminal Code of the Russian Federation, and only within the limits provided for by the relevant article of the Special Part of the Criminal Code of the Russian Federation.

3. The consolidation of the constitutional prohibition on cruel or degrading punishment (Part 2 of Art. 21 of the Constitution of the Russian Federation) necessitates a conceptual definition of these terms in the Criminal Code of the Russian Federation.

4. Restrictions and/or deprivation of human rights and freedoms in the content of criminal punishment are conditioned by the basic legal status of a person and a citizen.

5. Restrictions on rights and freedoms do not lead to a situation where these rights and freedoms lose their significance. "... In cases where constitutional norms allow the legislator to establish restrictions on the rights enshrined by them, they cannot carry out such regulation that would infringe on the very essence of one or another right and would lead to the loss of its real content ..." [10].

6. Implementation of the principle of humanism in criminal law means rejection of the punitive content of criminal punishment.

7.The practice of legislative regulation of legal liability in the Russian Federation shows that the list of types of criminal punishments cannot be regarded as open and cannot be supplemented and clarified by the court.

8. In Russian criminal legislation, the application of the principle of humanism is maximally limited in relation to terrorist crimes, which is associated with the special social danger of terrorist activity and its global threats [11].

\section{References}

1. S.I. Ozhegov, N.Yu. Shvedova, Explanatory Dictionary of the Russian Language, 4th ed. (Russian Academy of Sciences. Institute of the Russian language. V.V. Vinogradov; Azbukovnik, Moscow, 1999) 944 p.

2. I.T. Frolov (ed.), Philosophical Dictionary, (Politizdat, Moscow, 1986) 588 p. 
3. V.P. Kashepov, A.A. Gravina, T.O. Koshaeva et al., Humanization of modern criminal legislation: monograph (Institute of Legislation and Comparative Law under the Government of the Russian Federation, INFRA-M, Moscow, 2016) 336 p.

4. In the case of checking the constitutionality of paragraph "d" of Art. 18 of the RF Law "On Citizenship of the Russian Federation" in connection with the complaint of A.B. Smirnov: Resolution of the Constitutional Court of the Russian Federation of May 16, 1996 No. 12-P. Retrieved from: SPS "ConsultantPlus"

5. N.A. Lopashenko, The basics of criminal law impact: criminal justice, criminal law, criminal-law policy (R. Aslanov's Publishing House "Legal Center Press", St. Petersburg, 2004) 339 p.

6. V.N. Petrashev (ed.), Criminal law. General part (PRIOR, Moscow, 1999) 542 p.

7. The case of Del Río Prada v. Spain: Application No. 42750/09: European Regulation. Human Rights Court as of Oct. 21, 2013. Bulletin of the European Court of Human Rights, No. 2 (2014)

8. On the refusal to accept for consideration the complaints of citizen Andrey Anatolyevich Khoroshenko on violation of his constitutional rights by the provisions of part one of article 412 of the Criminal Procedure Code of the Russian Federation, part three of article 125 and part three of article 127 of the Criminal Executive Code of the Russian Federation: definition of the Constitution. Court of the Russian Federation dated May 24, 2005. No. 257-O. Retrieved from: SPS "ConsultantPlus".

9. In the case of checking the constitutionality of clause "b" of part three of Article 125 and part three of Article 127 of the Criminal Executive Code of the Russian Federation in connection with the request of the Vologda Regional Court and the complaint of citizens N.V. Korolev and V.V. Koroleva: Resolution of the Constitutional Court of the Russian Federation of November 15, 2016 No. 24-P. Retrieved from: SPS "ConsultantPlus".

10. In the case of checking the constitutionality of certain provisions of the Federal Law "On the Basic Guarantees of Electoral Rights and the Right to Participate in a Referendum of Citizens of the Russian Federation" in connection with a request from a group of State Duma deputies and complaints from citizens S.A. Buntman, K.A. Katanyan and K.S. Rozhkov: Decree of the Constitutional Court of the Russian Federation dated October 30. 2003 No. 15-P. Retrieved from: SPS "ConsultantPlus".

11. V.A. Avdeev, O.A. Avdeeva, S.V. Rozenko, E.V. Znamerovsky, E.A. Kiselev, Crime of the terrorist character and extremist orientation in the Russian Federation: state and measures of counteraction, Journal of Security and Sustainability, 7(2), 359-368 (2017) 